\title{
PMS2 wt Allele
}

National Cancer Institute

\section{Source}

National Cancer Institute. PMS2 wt Allele. NCI Thesaurus. Code C51003.

Human PMS2 wild-type allele is located in the vicinity of 7p22.2 and is approximately 36 $\mathrm{kb}$ in length. This allele, which encodes mismatch repair endonuclease PMS2 protein, plays a role in DNA mismatch repair. 